University of Nebraska - Lincoln

DigitalCommons@University of Nebraska - Lincoln

Agronomy \& Horticulture - Faculty Publications

Agronomy and Horticulture Department

$6-2020$

\title{
Irrigation, carbon amelioration, nitrogen, and stover removal effects on continuous corn
}

\author{
Marty Schmer \\ USDA, Agricultural Research Service, University of Nebraska-Lincoln, marty.schmer@ars.usda.gov \\ Virginia L. Jin \\ USDA-ARS, Agroecosystem Management Research UnitUSDA ARS, virginia.jin@ars.usda.gov \\ Richard B. Ferguson \\ University of Nebraska-Lincoln, rferguson1@unl.edu \\ Brian J. Wienhold \\ USDA-ARS, Agroecosystem Management Research Unit, Brian.Wienhold@ars.usda.gov
}

Follow this and additional works at: https://digitalcommons.unl.edu/agronomyfacpub

Part of the Agricultural Science Commons, Agriculture Commons, Agronomy and Crop Sciences Commons, Botany Commons, Horticulture Commons, Other Plant Sciences Commons, and the Plant Biology Commons

Schmer, Marty; Jin, Virginia L.; Ferguson, Richard B.; and Wienhold, Brian J., "Irrigation, carbon amelioration, nitrogen, and stover removal effects on continuous corn" (2020). Agronomy \& Horticulture -Faculty Publications. 1425.

https://digitalcommons.unl.edu/agronomyfacpub/1425

This Article is brought to you for free and open access by the Agronomy and Horticulture Department at DigitalCommons@University of Nebraska - Lincoln. It has been accepted for inclusion in Agronomy \& Horticulture -Faculty Publications by an authorized administrator of DigitalCommons@University of Nebraska - Lincoln. 
Agronomy, Soils, \& Environmental Quality

\title{
Irrigation, carbon amelioration, nitrogen, and stover removal effects on continuous corn
}

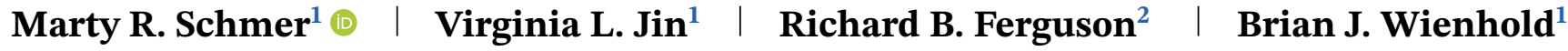

${ }^{1}$ USDA-ARS, Agroecosystem Management Research Unit, 251 Filley Hall, East Campus, University of Nebraska, Lincoln, NE 68583-0937, USA

${ }^{2}$ University of Nebraska, Dept of Agronomy and Horticulture, Lincoln, NE 68583 , USA

\section{Correspondence}

Marty R. Schmer, USDA-ARS, Agroecosystem Management Research Unit, 251 Filley Hall, East Campus, University of Nebraska, Lincoln NE 68583-0937, USA Email: marty.schmer@usda.gov

The U.S. Department of Agriculture (USDA) prohibits discrimination in all its programs and activities on the basis of race, color, national origin, age, disability, and where applicable, sex, marital status, family status, parental status, religion, sexual orientation, genetic information, political beliefs, reprisal, or because all or part of an individual's income is derived from any public assistance program. (Not all prohibited bases apply to all programs.) USDA is an equal opportunity provider and employer. Mention of commercial products and organizations in this manuscript is solely to provide specific information. It does not constitute endorsement by USDA-ARS over other products and organizations not mentioned.

\begin{abstract}
Corn (Zea mays L.) residue or stover is harvested as supplemental feed for livestock and is a potential feedstock for cellulosic biofuels. Limited information is available on corn stover removal effects on grain yield under different irrigation rates, nitrogen $(\mathrm{N})$ fertilizer rates, and practices to maintain soil carbon $(\mathrm{C})$ and minimize soil erosion. We evaluated potential interactions between irrigation rate (full or limited), C amelioration practices (cover crop, surface-applied manure, or no amelioration practice), fertilizer $\mathrm{N}$ management (125 or $200 \mathrm{~kg}$ $\mathrm{N} \mathrm{ha}^{-1}$ ), and stover removal (residue removal or no residue removal), on no-till continuous corn grain yield located on a silt loam soil in south-central Nebraska (2011-2018). Stover removal increased $(P=.0017)$ grain yield by $1.02 \mathrm{Mg} \mathrm{ha}^{-1}$ and grain $\mathrm{N}$ uptake compared with no stover removal. Manure increased corn grain yield by $899 \mathrm{~kg} \mathrm{ha}^{-1}$ compared to either the control or cover crop with stover removal while $\mathrm{C}$ amelioration practices did not affect grain yield under stover retention. Grain $\mathrm{N}$ concentration was higher $(P<.0001)$ with stover removal $\left(13.2 \mathrm{~g} \mathrm{~kg}^{-1}\right)$ than residue retained $\left(12.7 \mathrm{~g} \mathrm{~kg}^{-1}\right)$. Partial factor productivity (grain yield/N rate) was highest for manure treatments with residue removal. The farmgate $\mathrm{N}$ balance ( $\mathrm{N}$ applied $-\mathrm{N}$ removed) from stover removal was negative, yet grain yield was not affected after eight growing seasons. Grain yield increased with stover removal and manure application resulting in a cost-effective $\mathrm{C}$ amelioration practice whereas incorporating a winter cover crop resulted in similar grain yield as the control.
\end{abstract}

\section{1 | INTRODUCTION}

Corn (Zea mays L.) stover is mechanically harvested on 0.81 million ha in the United States for livestock feed and bedding purposes but is also considered a primary feedstock for cellulosic biofuels (Mitchell et al., 2016; Schmer, Brown, Jin, Mitchell, \& Redfearn, 2017). The relative affordability of corn stover as an animal feed compared to other forages and its potential as a low-carbon transportation fuel may result in increased stover use (Locker et al., 2019; Redfearn et al., 2019). Corn stover and other crop residues provide essential soil benefits such as wind 
and water erosion protection, soil $\mathrm{C}$ cycling, and nutrient storage (Jin et al., 2017; Wilhelm et al., 2010). Excessive stover harvests, either for livestock or biofuels may lead to soil C loss, yield declines, and increased erosion risk (Blanco-Canqui et al., 2014; Halvorson \& Stewart, 2015; Jin et al., 2015; Wilhelm et al., 2010). Conversely, excessive stover accumulation on the soil surface can decrease grain yield through planting interference, decreased seed emergence, and increased disease incidence (Sindelar, Coulter, Lamb, \& Vetsch, 2013; Verma et al., 2005).

Irrigated, continuous corn systems are prevalent in the western Corn Belt Region Grassini, Thorburn, Burr, \& Cassman, 2011. Irrigated corn production in central Nebraska tends to be high-yielding with high $\mathrm{N}$ inputs (Grassini \& Cassman, 2012). Interactions between irrigation and $\mathrm{N}$ fertilizer rate indicated that $\mathrm{N}$ fertilizer increased crop water use efficiency and irrigation water use efficiency in no-till continuous corn (Rudnick et al., 2016). However, a yield penalty is typically found for continuous corn compared with corn-soybean [Glycine Max L., (Merr.)] rotations (Farmaha et al., 2016; Seifert, Roberts, \& Lobell, 2017; Varvel \& Pederson, 1990). Primary causes for the continuous corn yield penalty are $\mathrm{N}$ availability, residue accumulation, and hot or dry weather events (Gentry, Ruffo, \& Below, 2013). In addition, N fertilizer recommendations for continuous corn systems are higher than in corn-soybean systems due to increased $\mathrm{N}$ immobilization in continuous corn systems (Varvel \& Pederson, 1990). Stover removal in continuous corn can increase plant productivity and $\mathrm{N}$ uptake (Sawyer, Woli, Barker, \& Pantoja, 2017), and may reduce the yield penalty associated with continuous corn systems compared with a corn-soybean rotation and reduce the need for additional $\mathrm{N}$ fertilizer requirements (Pantoja, Woli, Sawyer, Barker, \& Al-Kaisi, 2015; Sims, Schepers, Olson, \& Power, 1998; Sindelar et al., 2013; Wortmann, Shapiro, \& Schmer, 2016). Grain and stover removal, however, may alter $\mathrm{N}$ cycling and result in $\mathrm{N}$ deficits (greater $\mathrm{N}$ removal than $\mathrm{N}$ application) or a negative $\mathrm{N}$ balance, which could affect overall productivity in the long-term.

Carbon amendment or amelioration practices have been proposed to reduce negative effects from stover removal related to changes in soil properties, particularly in no-till systems (Ruis \& Blanco-Canqui, 2017). Incorporating a winter cover crop is one $\mathrm{C}$ amelioration practice to prevent soil organic carbon (SOC) loss and limit erosion but limited information is available on yield effects within a continuous corn system (Blanco-Canqui, Wortmann, \& Kreikemeier, 2017; Ruis, Blanco-Canqui, Jasa, Ferguson, \& Slater, 2017). In a meta-analysis, winter cover crop effects on subsequent corn yields tend to be neutral or positive (Marcillo \& Miguez, 2017) while also effective in reducing nitrate leaching in agricultural systems (Kaye et al., 2019;

\section{Core ideas}

- Stover removal resulted in increased grain yield and crop nitrogen uptake.

- The farmgate nitrogen balance from stover removal was negative.

- Surface-applied manure is a viable carbon amelioration practice when stover is removed.

Quemada, Baranski, Nobel-de Lange, Vallejo, \& Cooper, 2013). Winter rye (Secale cereale L.) resulted in similar continuous corn yield as no cover crop on an irrigated, sandy loam field site (Blanco-Canqui et al., 2017). Applying manure partially offsets valuable nutrients and $C$ that are removed from corn stover harvest (Thelen, Fronning, Kravchenko, Min, \& Robertson, 2010). In addition, manure application with stover removal can result in negative global warming potential (Fronning, Thelen, \& Min, 2008).

Previous research on stover removal in an irrigated system showed grain yield was not affected by stover removal or tillage on a silt loam soil but grain yield increased with stover removal under moderate $\mathrm{N}$ rates on a silty clay loam soil (Sims et al., 1998). Over 10 growing seasons on a silt loam soil, irrigated, no-till corn yields were $8-9 \%$ higher under medium to high stover removal rates than with no stover removal (Schmer, Varvel, Follett, Jin, \& Wienhold, 2014). Irrigated, no-till corn yield was $20 \%$ higher with stover removal than with no stover removal (Wortmann et al., 2016). Stover removal in Colorado on a clay loam soil increased spring soil temperatures and resulted in increased irrigated corn yields compared with retaining stover (Halvorson \& Stewart, 2015). Other studies have shown similar corn grain yields between stover removal and stover retained for irrigated, continuous corn systems in this region (Blanco-Canqui et al., 2017; Kenney et al., 2015; Stalker et al., 2015).

Limited studies have evaluated potential interactions between irrigation rate, $\mathrm{C}$ amelioration practices, fertilizer $\mathrm{N}$ management, and stover removal on grain yield. Our primary study objectives were to evaluate stover removal effects on grain yield under variable irrigation, $\mathrm{C}$ amelioration, and $\mathrm{N}$ practices in a no-till, continuous corn system. Secondary study objectives were to evaluate corn stover removal on nitrogen use efficiency (NUE) and determine the farmgate $\mathrm{N}$ balance from stover removal.

\section{2 | MATERIAL AND METHODS}

The experimental site is located at the University of Nebraska-Lincoln's South Central Agricultural 
TA B L E 1 Corn hybrid, seeding, and irrigation rate information for a continuous corn study near Clay Center, NE

\begin{tabular}{|c|c|c|c|c|c|}
\hline \multirow[b]{2}{*}{ Year } & \multirow[b]{2}{*}{ Hybrid } & \multicolumn{2}{|c|}{ Corn planting } & \multicolumn{2}{|c|}{ Irrigation rate } \\
\hline & & $\overline{\text { Date }}$ & Rate & Full & Limited \\
\hline & & & Number of plants ha $\mathrm{h}^{-1}$ & \multicolumn{2}{|c|}{$-\mathrm{mm}$} \\
\hline 2011 & Pioneer 541 AM-RR & 29 Apr. & 72,896 & 135 & 81 \\
\hline $20125 n$ & Pioneer P1498HR & 24 Apr. & 84,015 & 196 & 121 \\
\hline 2015 & DeKalb 60-67 & 1 May & 84,772 & 203 & 122 \\
\hline 2016 & DeKalb 60-67 & 13 May & 84,017 & 236 & 142 \\
\hline 2017 & DeKalb 60-67 & 7 May & 83,980 & 170 & 100 \\
\hline 2018 & Dekalb 60-67 & 1 May & 83,950 & 135 & 81 \\
\hline
\end{tabular}

Laboratory $\left(40.582^{\circ} \mathrm{N}, 98.144^{\circ} \mathrm{W} ; 552 \mathrm{~m}\right.$ asl) located near Clay Center, NE with a climatic zone between subhumid and semiarid. Long-term mean annual temperature is $10.3{ }^{\circ} \mathrm{C}$ and mean annual precipitation is $731 \mathrm{~mm}$, with $447 \mathrm{~mm}$ (1983-2014) occurring during the growing season (Apr.-Oct.). The study site is on a Hastings silt loam (fine, smectitic, mesic Udic Argiustolls) with a 0-2\% slope. Surface soil chemical and physical properties have previously been reported (Blanco-Canqui et al., 2014; Sindelar, Blanco-Canqui, Jin, \& Ferguson, 2019). The site was previously in soybean prior to study initiation in a ridge-till system. The site was tilled using a field-disk $(0-15 \mathrm{~cm})$ in April 2010 to level the soil surface and has been in no-till since. Experiment was established in 2010.

The experimental design is a randomized complete block and treatment design is split-split-split factorial with four replications for each treatment factor. The main plot is irrigation level (full or limited) with plot dimension 24 by $155 \mathrm{~m}$. The field was irrigated using a variable-rate linear lateral move irrigation system (Valmont, Valley, $\mathrm{NE})$. Irrigation timing was managed to maintain between 45 and $90 \%$ of total available soil water within the $1.2-\mathrm{m}$ soil profile to minimize plant water stress and drainage. Limited irrigation events were applied at the same time as full irrigation events and were $60 \%$ of the total applied compared to the full irrigation treatment. Available soil water was measured using Watermark Granular Matrix sensors (Irrometer, Riverside, CA), which measures soil matric potential. The soil matric potential measurements were converted to soil volumetric water content using a site-specific soil-water retention curve for the study site (Irmak, 2015; Rudnick et al., 2015). Soil matric potential sensors were installed at $0.3-\mathrm{m}$ increments to a soil depth of $1.2 \mathrm{~m}$. Irrigation amounts are reported in Table 1 for full irrigation and limited irrigation treatments.

The split-plot factor ( 24 by $52 \mathrm{~m}$ ) was $\mathrm{C}$ amelioration treatments (cover crop, manure, or control). A monocul- ture of winter cereal rye (Secale cereale L.) was the cover crop used. Cereal rye was planted after stover harvest in the fall at a rate of $112 \mathrm{~kg} \mathrm{ha}^{-1}$. Cereal rye was planted (late Oct.) using a 1590 John Deere no-till drill (Deere \& Co. Moline, IL) with a $19-\mathrm{cm}$ row spacing. The cereal rye cover crop was terminated 2 wk prior to corn planting using glyphosate ( $N$-[phosphonomethyl] glycine). Manure was applied in the fall every $2 \mathrm{yr}$ (2010, 2012, 2014, and 2016) using a mechanical manure spreader after corn grain and stover harvests. Sheep manure was applied in 2010 and beef cattle manure was applied in 2012, 2014, and 2016. Manure was applied that approximated P removal from corn grain harvest (Blanco-Canqui et al., 2014). From 2010 to 2016, the average manure application rate was $25.6 \pm 1.7 \mathrm{Mg} \mathrm{ha}^{-1}$ fresh weight $\left(14.2 \pm 2.5 \mathrm{Mg}\right.$ dry matter ha $\left.{ }^{-1}\right)$. Average N, P, and $\mathrm{K}$ percent from manure was 1.9, 1.6, and 3.3\%, respectively or $9.8 \mathrm{~kg} \mathrm{~N} \mathrm{Mg}^{-1}, 8.8 \mathrm{~kg} \mathrm{P} \mathrm{Mg}^{-1}$, and $16.1 \mathrm{~kg} \mathrm{~K} \mathrm{Mg}^{-1}$ (fresh weight). Following manure application, $\mathrm{N}$ manure was credited to the amount of inorganic $\mathrm{N}$ applied at sidedress to meet experimental $\mathrm{N}$ treatment levels based on first $(25 \%)$ and second (12\%) year organic $\mathrm{N}$ mineralization (Koelsch \& Shapiro, 2006; Wortmann \& Shapiro, 2008).

Split-split plot dimensions are 12 by $52 \mathrm{~m}$ and consist of stover removed or stover retained treatment plots. Stover was mechanically harvested to remove the maximum under field conditions. In the fall of 2010 and 2011, a flail shredder, a high-capacity hay rake, and round baler was used to remove corn stover while in 2012, 2013, 2014, 2015, and 2016 a self-propelled disk mower-conditioner and round baler were used. For 2017 and 2018, a tractor mounted disk mower, high capacity rake, and round baler were used. Corn stalks were cut at a height of 5 $\mathrm{cm}$ to maximize stover removal amounts. Stover removal was done in late October following grain harvest but prior to cover crop planting. Corn stover was sampled from each stover harvest treatment plot prior to baling to determine moisture percentage and analyzed for $\mathrm{C}$ 
and $\mathrm{N}$. The baler was weighed using portable truckscale load cells (Intercomp PT300, Intercomp, Medina, $\mathrm{MN})$ at the beginning and end of each harvested stover removal plot.

Split-split-split treatment plots consisted of $\mathrm{N}$ fertilizer rate $\left(125\right.$ and $\left.200 \mathrm{~kg} \mathrm{~N} \mathrm{ha}^{-1}\right)$. Split-split-split plot dimensions were 12 by $26 \mathrm{~m}$. Nitrogen fertilization (urea ammonium nitrate solution; 32-0-0) was applied post corn emergence using a sidedress coulter injection system.

Corn was planted in late April or May (Table 1) in 76-cm rows. Corn plant counts were taken in 2012-2017 from a 12.1-m length of row at corn leaf stage V6. Aboveground dry matter samples from a 0.76-m wide, 3.04-m long area from all corn plots were hand collected every year soon after physiological maturity (Sept. or early Oct.). Ears were removed, dried, and weighed. Stalks were cut at ground level, chopped, and weighed, and a subsample was dried at $60{ }^{\circ} \mathrm{C}$ until constant mass was reached for calculation of stover dry matter production. Hand harvest grain yields were determined from the dry mass of grain shelled from ears collected in the 3.04-m length of row. A subsample of dried grain was analyzed for $\mathrm{C}$ and $\mathrm{N}$ content. After shelling, cob weights were added to the calculated stover weight to obtain total nongrain dry matter (stover) production. Nongrain biomass parameters are reported on a drymatter basis. To better account for spatial variability within the study, grain yields were obtained using a commercialscale combine. A total of four rows were mechanically harvested (rows 5, 6, 12, and 13) for grain yield determination. Corn grain yields are reported to a moisture content of $155 \mathrm{~g} \mathrm{~kg}^{-1}$. Harvest index (HI) and NUE measures (Equations 1-5) were derived from Woli et al. (2016) and Sawyer et al. (2017). In addition, we calculated a simplified $\mathrm{N}$-balance (Equation 6) to estimate $\mathrm{N}$ surpluses and deficits (McLellan et al., 2018). Equations 1-5 are derived from physiological maturity harvests and reported on a dry matter basis.

$$
\text { Harvest index }(\mathrm{HI})=\frac{\text { grain biomass }}{\text { total plant biomass }}
$$

$$
\text { Nitrogen harvest index }(\mathrm{NHI})=\frac{\text { grain } \mathrm{N} \text { uptake }}{\text { total plant } \mathrm{N} \text { uptake }}
$$

Partial factor productivity $(\mathrm{PFP})\left(\mathrm{kgkg}^{-1}\right)=\frac{\text { grain yield }}{\mathrm{N} \text { rate }}$

Internal $\mathrm{N}$ efficiency (INE) $\left(\mathrm{kgkg}^{-1}\right)$

$$
=\frac{\text { grain yield }}{\text { total plant } \mathrm{N} \text { uptake }}
$$

System N efficiency $(\mathrm{SNE})(\%)=\frac{\text { grain } \mathrm{N} \text { uptake }}{\mathrm{N} \text { rate }} 100$

Farm - gate grain or stover and grain $\mathrm{N}$ balance $\left(\mathrm{kg} \mathrm{N} \mathrm{ha}^{-1}\right)$

$=[\mathrm{N}$ rate $-($ grain $\mathrm{N}$ uptake + harvested stover $\mathrm{N})]$

Where $\mathrm{N}$ rate includes both manure $\mathrm{N}$ and/or inorganic $\mathrm{N}$ fertilizer rates.

\section{3 | DATA ANALYSIS}

Total biomass yield, grain yield, grain moisture, HI, stand density, and NUE measures was analyzed using the GLIMMIX procedure of SAS (v. 9.3) using a .05 probability level (SAS Institute, 2014). Experimental design was a randomized complete block with a split-split-split plot treatment arrangement with four replicates for each treatment factor. Analysis was performed across years. Treatments and interactions were considered fixed while years, replicates, and subsequent interactions were considered random. The covariance structure that gave the smallest Akaike information criteria was used for each parameter. Differences between treatment least square means were determined using the LINES option as well as the SLICE and SLICEDIFF options when interaction effects were significant $(P \leq .05)$.

\section{4 | RESULTS}

\section{1 | Total biomass, grain yield, grain moisture, and harvest index}

Total biomass, grain yield, grain moisture, and HI were similar by irrigation practice (Table 2). Total biomass increased with amelioration practice and $\mathrm{N}$ rate whereas grain yield increased with $\mathrm{N}$ rate and stover removal (Figure 1; Table 3). Stover removal harvest averaged $5.7 \mathrm{Mg} \mathrm{ha}^{-1}$ or $59 \%$ of the total stover was removed within the stover removed treatment factor. The $200 \mathrm{~kg} \mathrm{~N} \mathrm{ha}^{-1}$ rate resulted in a $2.6 \mathrm{Mg} \mathrm{ha}^{-1}$ increase in total biomass compared with the $125 \mathrm{~kg} \mathrm{~N} \mathrm{ha}^{-1}$ rate. Surface applied manure resulted in 1.0 $\mathrm{Mg} \mathrm{ha}^{-1}$ and $1.1 \mathrm{Mg} \mathrm{ha}^{-1}$ increase in total biomass more than either cover crop or the control, respectively (Table 3).

Overall, manure application under stover harvest resulted in grain yields of $13.1 \mathrm{Mg} \mathrm{ha}^{-1}$, which was significantly higher (Figure 1a) than cover crops $\left(12.2 \mathrm{Mg} \mathrm{ha}^{-1}\right)$ or the control $\left(12.2 \mathrm{Mg} \mathrm{ha}^{-1}\right)$. Amelioration practices did not affect grain yield under stover retention, but manure 
TA B L E 2 Significance of $P$-values for fixed source of variation for total corn plant dry matter, grain yield, grain moisture, harvest index, and corn stand density affected by irrigation (I), carbon amendment (C), fertilizer nitrogen rate (N), and stover removal (R)

\begin{tabular}{|c|c|c|c|c|c|c|}
\hline Source of variation & $d f$ & Total biomass & Grain yield & Grain moisture & Harvest index & Stand density \\
\hline Irrigation (I) & 1 & .0602 & .1225 & .2562 & .0992 & .4167 \\
\hline $\mathrm{C}$ amendment (C) & 2 & $.0273^{a}$ & .0009 & .0130 & .0911 & .1200 \\
\hline Nitrogen $(\mathrm{N})$ & 1 & $<.0001$ & $<.0001$ & $<.0001$ & .0378 & .9676 \\
\hline $\mathrm{I} \times \mathrm{C}$ & 2 & .7475 & .9289 & .7210 & .5570 & .8361 \\
\hline $\mathrm{C} \times \mathrm{R}$ & 2 & .2140 & .0014 & .1374 & .5796 & .8152 \\
\hline $\mathrm{C} \times \mathrm{N}$ & 2 & .3878 & .8027 & .8046 & .4254 & .9710 \\
\hline $\mathrm{R} \times \mathrm{N}$ & 1 & .2518 & .0158 & .7469 & .0312 & .7108 \\
\hline $\mathrm{I} \times \mathrm{R} \times \mathrm{C}$ & 2 & .3183 & .9467 & .6946 & .4479 & .1731 \\
\hline $\mathrm{I} \times \mathrm{C} \times \mathrm{R} \times \mathrm{N}$ & 2 & .0565 & .7471 & .8095 & .6881 & .5644 \\
\hline
\end{tabular}

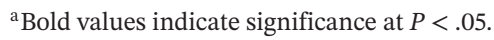

TA B L E 3 Main effect least square means of total biomass, grain moisture, harvest index, and corn stand density by irrigation, C amelioration practice, $\mathrm{N}$ rate $\left(\mathrm{kg} \mathrm{ha}^{-1}\right)$, and stover harvest. Significant treatment differences are indicated by different letters between levels within each main effect

\begin{tabular}{|c|c|c|c|c|}
\hline & Total biomass & Grain moisture & Harvest index & Stand density \\
\hline & $\mathrm{Mg} \mathrm{ha}^{-1}$ & $\mathrm{~g} \mathrm{~kg}^{-1}$ & & plants ha ${ }^{-1}$ \\
\hline \multicolumn{5}{|l|}{ Irrigation } \\
\hline Limited & 20.7 & 16.8 & 0.53 & 79,561 \\
\hline SEM $^{\mathrm{a}}$ & 0.25 & 0.15 & 0.003 & 292 \\
\hline Cover crop & $20.7 b$ & $16.9 \mathrm{ab}$ & 0.53 & 80,201 \\
\hline Manure & $21.7 \mathrm{a}$ & $17.1 \mathrm{a}$ & 0.53 & 79,729 \\
\hline SEM & 0.29 & 0.15 & 0.004 & 346 \\
\hline \multicolumn{5}{|l|}{ Stover } \\
\hline \multicolumn{5}{|l|}{$\mathrm{N}$ rate } \\
\hline 125 & $19.7 b$ & $16.6 b$ & $0.53 b$ & 79,722 \\
\hline 200 & $22.3 \mathrm{a}$ & $17.2 \mathrm{a}$ & $0.54 \mathrm{a}$ & 79,707 \\
\hline SEM & 0.23 & 0.15 & 0.004 & 282 \\
\hline
\end{tabular}

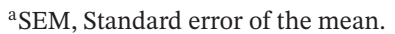

application did result in higher grain yield with stover harvest (Figure $1 \mathrm{~b}$ ). As expected, the main effect of $\mathrm{N}$ rate was significant (Table 2), with a $1.41 \mathrm{Mg} \mathrm{ha}^{-1}$ increase in grain yield from the $200 \mathrm{~kg} \mathrm{~N}^{-1}$ application rate compared to the $125 \mathrm{~kg} \mathrm{~N} \mathrm{ha}^{-1}$ application rate (Figure 1c).
A significant stover harvest $\times \mathrm{N}$ fertilizer rate interaction $(P=.0158)$ was also present (Figure 1d). Highest grain yield was from the $200 \mathrm{~kg} \mathrm{~N} \mathrm{ha}^{-1}$ rate with stover harvest (13.1 $\mathrm{Mg} \mathrm{ha}^{-1}$ ), followed by $200 \mathrm{~kg} \mathrm{~N} \mathrm{ha}^{-1}$ rate with stover retention $\left(12.3 \mathrm{Mg} \mathrm{ha}^{-1}\right)$, then $125 \mathrm{~kg} \mathrm{~N} \mathrm{ha}^{-1}$ with stover 

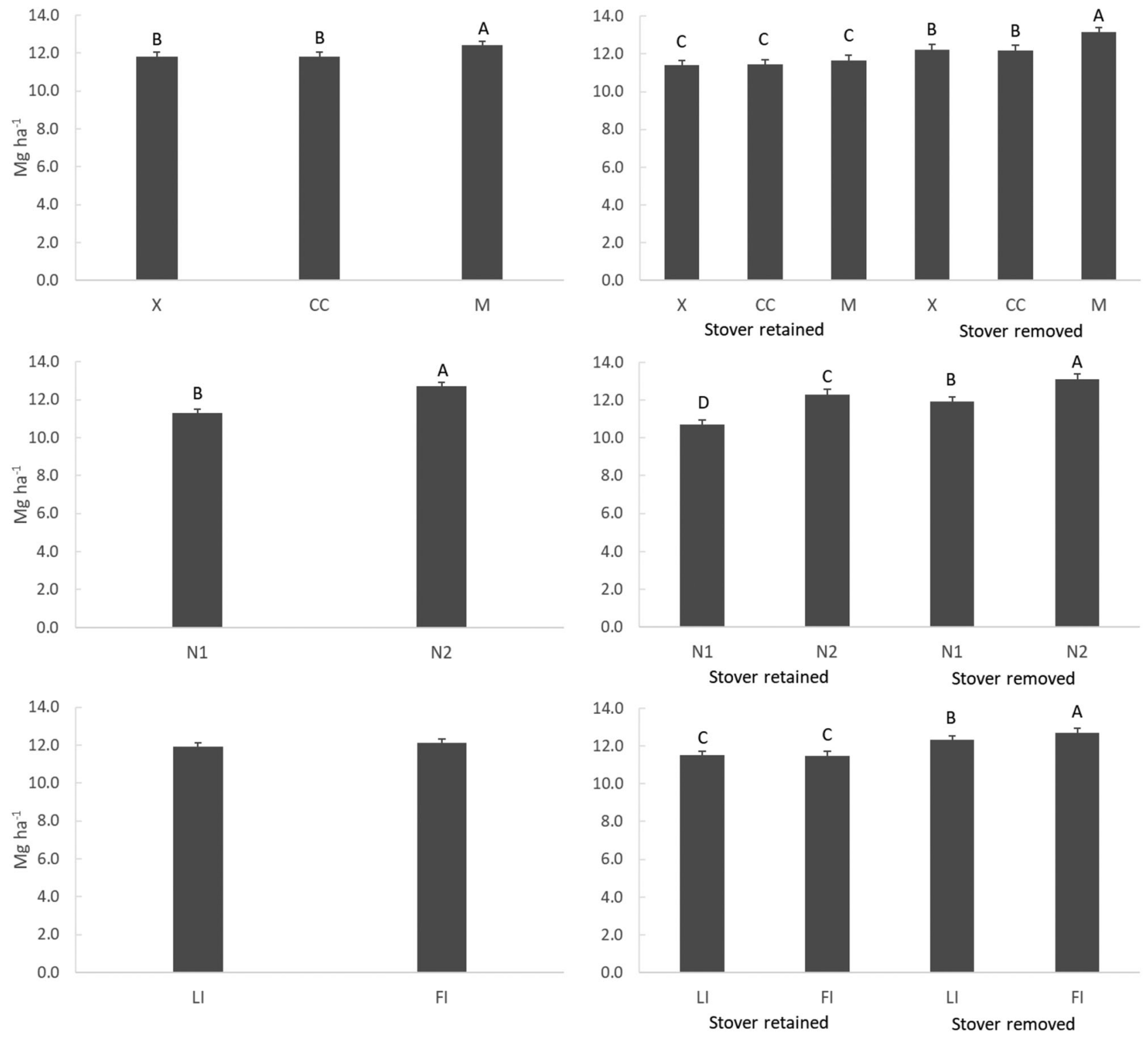

F I G U R E 1 Grain yield response to carbon amelioration practices (a; X, control; CC, cover crop; M, manure), the interaction of carbon amelioration and stover removal (b), $\mathrm{N}$ rate (c; $\mathrm{N} 1,125 \mathrm{~kg} \mathrm{~N} \mathrm{ha}^{-1} ; \mathrm{N} 2,200 \mathrm{~kg} \mathrm{~N} \mathrm{ha}^{-1}$ ), the interaction of $\mathrm{N}$ rate and stover removal (d), irrigation rate (e; LI, limited irrigation; FI, full irrigation), and the interaction between irrigation and stover removal (f). Error bars indicate upper $95 \%$ confidence interval and uppercase letters indicate significance at $P \leq .05$

harvest (11.9 $\left.\mathrm{Mg} \mathrm{ha}^{-1}\right)$, and $125 \mathrm{~kg} \mathrm{~N} \mathrm{ha}^{-1}$ with stover retention $\left(10.7 \mathrm{Mg} \mathrm{ha}^{-1}\right)$. Stover removal resulted in an increase $(P=.0017)$ in grain yield compared to stover retention (Figure 1e). Differences in grain yield between stover harvest and stover retained treatments were not the result of corn population differences, as plant counts taken at V6 were similar, averaging 78,941 plants $\mathrm{ha}^{-1}$ across years (Tables 2,3 ). Irrigation rate did not affect grain yield under stover retention treatments, but full irrigation grain yields were higher $\left(12.7 \mathrm{Mg} \mathrm{ha}^{-1}\right)$ than limited irrigation (12.3 $\mathrm{Mg} \mathrm{ha}^{-1}$ ) under stover removal (Table 2; Figure 1f).

Grain moisture was similar $(P=.2562)$ by irrigation rate (Table 3). The $\mathrm{C}$ amelioration main effect was significant
$(P=.0130)$ with surface-applied manure treatments having higher moisture content $\left(171 \mathrm{~g} \mathrm{~kg}^{-1}\right)$ compared to the control (167 $\left.\mathrm{g} \mathrm{kg}^{-1} ; P=.0033\right)$. Nitrogen rate affected grain moisture $(P<.0001)$ with the $125 \mathrm{~kg} \mathrm{~N}^{-1}$ rate resulting in lower grain moisture $\left(166 \mathrm{~g} \mathrm{~kg}^{-1}\right)$ than the $200 \mathrm{~kg} \mathrm{~N} \mathrm{ha}^{-1}$ rate $\left(172 \mathrm{~g} \mathrm{~kg}^{-1}\right)$. Grain moisture was higher $(P<.0001)$ for stover retained $\left(175 \mathrm{~g} \mathrm{~kg}^{-1}\right)$ than stover harvested treatments $\left(162 \mathrm{~g} \mathrm{~kg}^{-1}\right)$ at combine harvest (Table 3).

Harvest index was higher in the $200 \mathrm{~kg} \mathrm{~N} \mathrm{ha}^{-1}$ rate $(\mathrm{HI}=.54)$ compared to the $125 \mathrm{~kg} \mathrm{~N} \mathrm{ha}^{-1}$ rate $(\mathrm{HI}=.53$; Table 3). Stover removal also increased HI (.55) compared to stover retention (.52). A $\mathrm{N}$ rate $\times$ stover harvest 
TA B L E 4 Significance of $P$-values for fixed source of variation for fixed source of variation for nitrogen use efficiency indicators of grain $\mathrm{N}$ concentration (GNC), nitrogen harvest index (NHI), partial factor productivity (PFP), internal N efficiency (INE), system N efficiency (SNE), and grain $\mathrm{N}$ balance

\begin{tabular}{|c|c|c|c|c|c|c|c|}
\hline Source of variation & $d f$ & GNC & NHI & INE & PFP & SNE & Grain $\mathbf{N}$ balance \\
\hline Irrigation (I) & 1 & .1529 & .8931 & .5332 & .1253 & .4047 & .4815 \\
\hline C amendment (C) & 2 & $.0012^{\mathrm{a}}$ & .0131 & .0037 & .0010 & .0062 & .0055 \\
\hline Nitrogen (N) & 1 & $<.0001$ & .2865 & $<.0001$ & $<.0001$ & $<.0001$ & .0003 \\
\hline $\mathrm{I} \times \mathrm{C}$ & 2 & .6294 & .1368 & .8430 & .9543 & .8816 & .9017 \\
\hline $\mathrm{C} \times \mathrm{R}$ & 2 & .4338 & .7884 & .7421 & .0034 & .9466 & .9401 \\
\hline $\mathrm{C} \times \mathrm{N}$ & 2 & .0677 & .9474 & .3752 & .0401 & .3133 & .2806 \\
\hline $\mathrm{R} \times \mathrm{N}$ & 1 & .1285 & .0606 & .5841 & .0001 & .0652 & .3708 \\
\hline $\mathrm{I} \times \mathrm{R} \times \mathrm{C}$ & 2 & .5333 & .5234 & .4294 & .9783 & .3616 & .4512 \\
\hline $\mathrm{I} \times \mathrm{CxR} \times \mathrm{N}$ & 2 & .1754 & .8856 & .1245 & .7515 & .2048 & .1506 \\
\hline
\end{tabular}

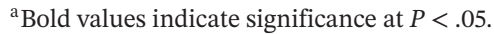

interaction was found for HI (Table 2). Overall, HI differed between stover retention at the $200 \mathrm{~kg} \mathrm{~N} \mathrm{ha}^{-1}$ fertilizer rate $(\mathrm{HI}=.52)$ and the $125 \mathrm{~kg} \mathrm{~N} \mathrm{ha}^{-1}$ rate $(\mathrm{HI}=.51)$. Stover removal resulted in similar $\mathrm{HI}$ for both the $200 \mathrm{~kg} \mathrm{~N} \mathrm{ha}^{-1}$ $(\mathrm{HI}=.55)$ and the $125 \mathrm{~kg} \mathrm{~N} \mathrm{ha}^{-1}(\mathrm{HI}=.55)$ and were higher than the stover retention $\mathrm{HI}$ values.

\section{2 | Nitrogen use efficiency}

Nitrogen use efficiency measures related to plant biomass or grain yield decreased with increased $\mathrm{N}$ rate (Figure 2). Main effects of amelioration practice, $\mathrm{N}$ rate, and stover harvest were significant for partial factor productivity (PFP; Table 4). Surface-applied manure, lower N rate, and stover harvest resulted in higher PFP values (Figure 2).

Two-way interactions of irrigation $\times$ stover, amelioration $\times \mathrm{N}$ fertilizer rate, amelioration $\times$ stover, and stover $\times \mathrm{N}$ fertilizer rate were also significant (Table 4 ). Surface-applied manure under the $125 \mathrm{~kg} \mathrm{~N} \mathrm{ha}^{-1}$ rate had higher PFP than the cover crop or control, whereas $\mathrm{C}$ amelioration practices was similar at the $200 \mathrm{~kg} \mathrm{~N} \mathrm{ha}^{-1}$ rate (Figure 2b). Stover removal fertilized at $125 \mathrm{~kg} \mathrm{~N} \mathrm{ha}^{-1}$ had the highest PFP value $\left(95 \mathrm{~kg} \mathrm{~kg}^{-1}\right)$ followed by stover retained at $125 \mathrm{~kg} \mathrm{~N} \mathrm{ha}^{-1}\left(86 \mathrm{~kg} \mathrm{~kg}^{-1}\right)$, stover removal at $200 \mathrm{~kg} \mathrm{~N} \mathrm{ha}^{-1}\left(73 \mathrm{~kg} \mathrm{~kg}^{-1}\right)$, and stover retained at $200 \mathrm{~kg}$ $\mathrm{N} \mathrm{ha}^{-1}$ (68 kg kg-1; Figure 2d). Stover removal resulted in higher PFP for both full $\left(85 \mathrm{~kg} \mathrm{~kg}^{-1}\right)$ and limited (83 kg $\mathrm{kg}^{-1}$ ) irrigation compared with stover retention (Figure 2f). Amelioration under stover retention had similar PFP val- ues while manure with stover removal had the highest PFP (88 kg kg ${ }^{-1}$; Figure 2h).

Carbon amelioration practice and $\mathrm{N}$ rate affected internal $\mathrm{N}$ efficiency (INE; Table 4). Both cover crop and the control had statistically higher INE values than manure (Table 5). The $125 \mathrm{~kg} \mathrm{~N} \mathrm{ha}^{-1}$ rate resulted in an INE value of $58 \mathrm{~kg} \mathrm{~kg}^{-1}$ while the $200 \mathrm{~kg} \mathrm{~N} \mathrm{ha}^{-1}$ was $50 \mathrm{~kg} \mathrm{~kg}^{-1}$ (Table 5). For INE, an irrigation $\times$ stover interaction was significant with full irrigation under stover removal having the highest INE value of $56 \mathrm{~kg} \mathrm{~kg}^{-1}$ but was statistically similar to limited irrigation with stover retained $\left(\mathrm{INE}=54 \mathrm{~kg} \mathrm{~kg}^{-1}\right)$. Both stover retained at full irrigation and stover removed at limited irrigation were statistically similar to limited irrigation with stover retained for INE. Nitrogen rate, stover removal, and $\mathrm{C}$ amelioration practice were significant for system $\mathrm{N}$ efficiency (SNE; Table 4). Manure amelioration had a significantly higher SNE (99.8\%) than either the control (93.6\%) or winter cover crop (92.8\%; Table 5). Similar to PFP and INE, the $125 \mathrm{~kg} \mathrm{~N} \mathrm{ha}^{-1}$ rate resulted in a higher SNE value (100.9\%) than the $200 \mathrm{~kg} \mathrm{~N} \mathrm{ha}^{-1}$ rate (89.9\%). Stover removal resulted in a 7\% increase for SNE (Table 5).

Main effects of stover removal and $\mathrm{C}$ amelioration practice was significant for nitrogen harvest index (NHI; Table 4). Stover removal resulted in higher NHI values (.65) than stover retention (.63). Cover crop had the highest NHI value (.65) and was higher $(P=.0039)$ than surface-applied manure (.64). Grain N concentration (GNC) differed by amelioration, $\mathrm{N}$ rate, and stover practice (Table 4). Grain $\mathrm{N}$ concentration from manure $\left(13.2 \mathrm{~g} \mathrm{~kg}^{-1}\right)$ was higher than either the cover crop $\left(12.8 \mathrm{~g} \mathrm{~kg}^{-1}\right)$ or the control 

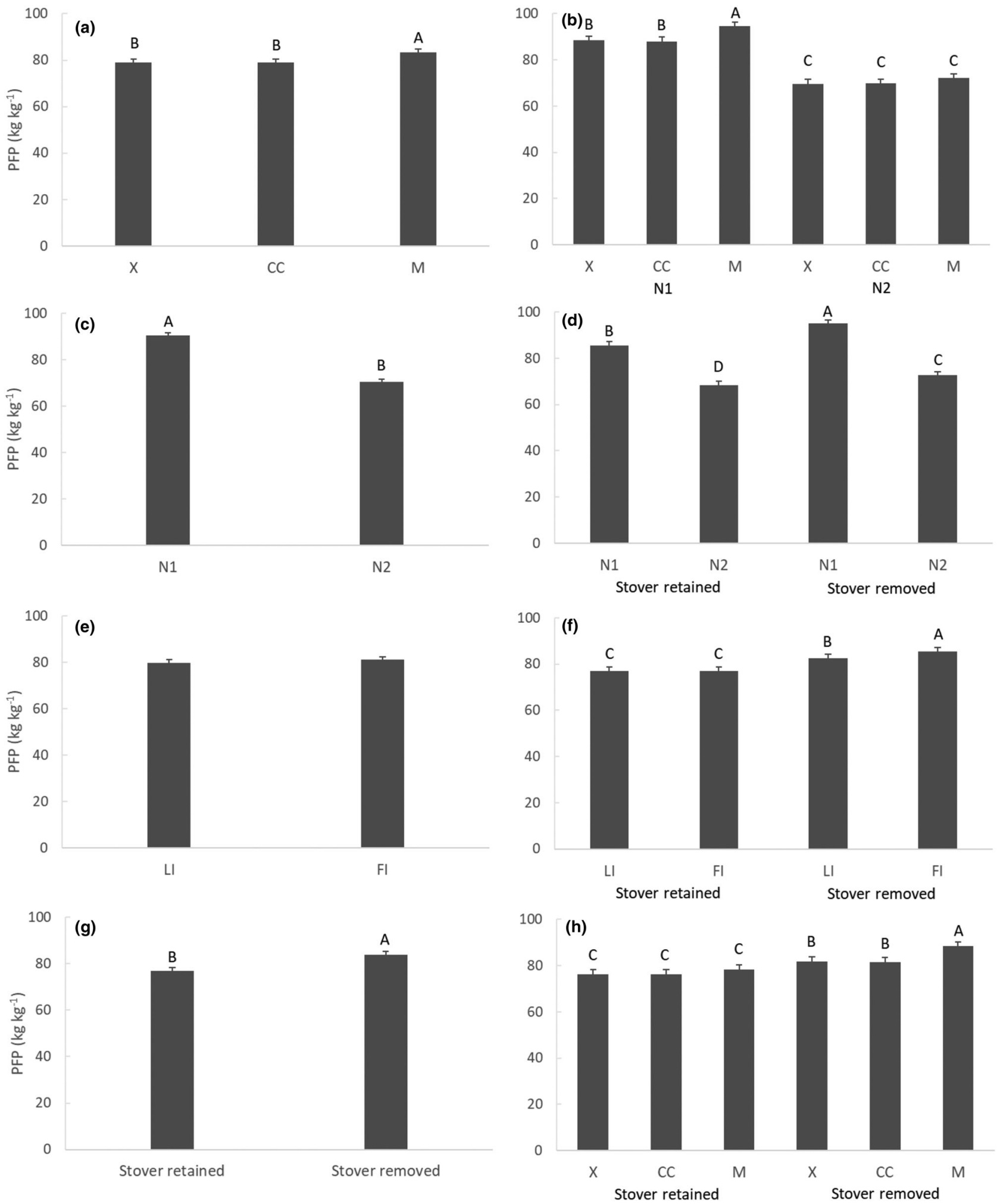

F I G U R E 2 Partial factor productivity (PFP) of N response to carbon amelioration practices (a; X, control; CC, cover crop; M, manure), the interaction of carbon amelioration and $\mathrm{N}$ rate (c; $\left.\mathrm{N} 1,125 \mathrm{~kg} \mathrm{~N} \mathrm{ha}^{-1} ; \mathrm{N} 2,200 \mathrm{~kg} \mathrm{~N} \mathrm{ha}^{-1}\right)(\mathrm{b}), \mathrm{N}$ rate (c), the interaction of $\mathrm{N}$ rate and stover removal (d), irrigation rate (e; LI, limited irrigation; FI, full irrigation), the interaction between irrigation and stover removal (f), stover harvest (g), and the interaction of stover harvest and carbon amelioration practice. Error bars indicate upper $95 \%$ confidence interval and uppercase letters indicate significance at $P \leq .05$ 
TA B L E 5 Main effect least square means of grain N concentration (GNC), nitrogen harvest index (NHI), internal N efficiency (INE), system $\mathrm{N}$ efficiency (SNE), farmgate grain $\mathrm{N}$ balance (GNB), and farmgate grain $\mathrm{N}+$ stover $\mathrm{N}$ balance (G+SNB) by irrigation, $\mathrm{C}$ amelioration practice, $\mathrm{N}$ rate, and stover harvest. Significant treatment differences are indicated by different letters between levels within each main effect

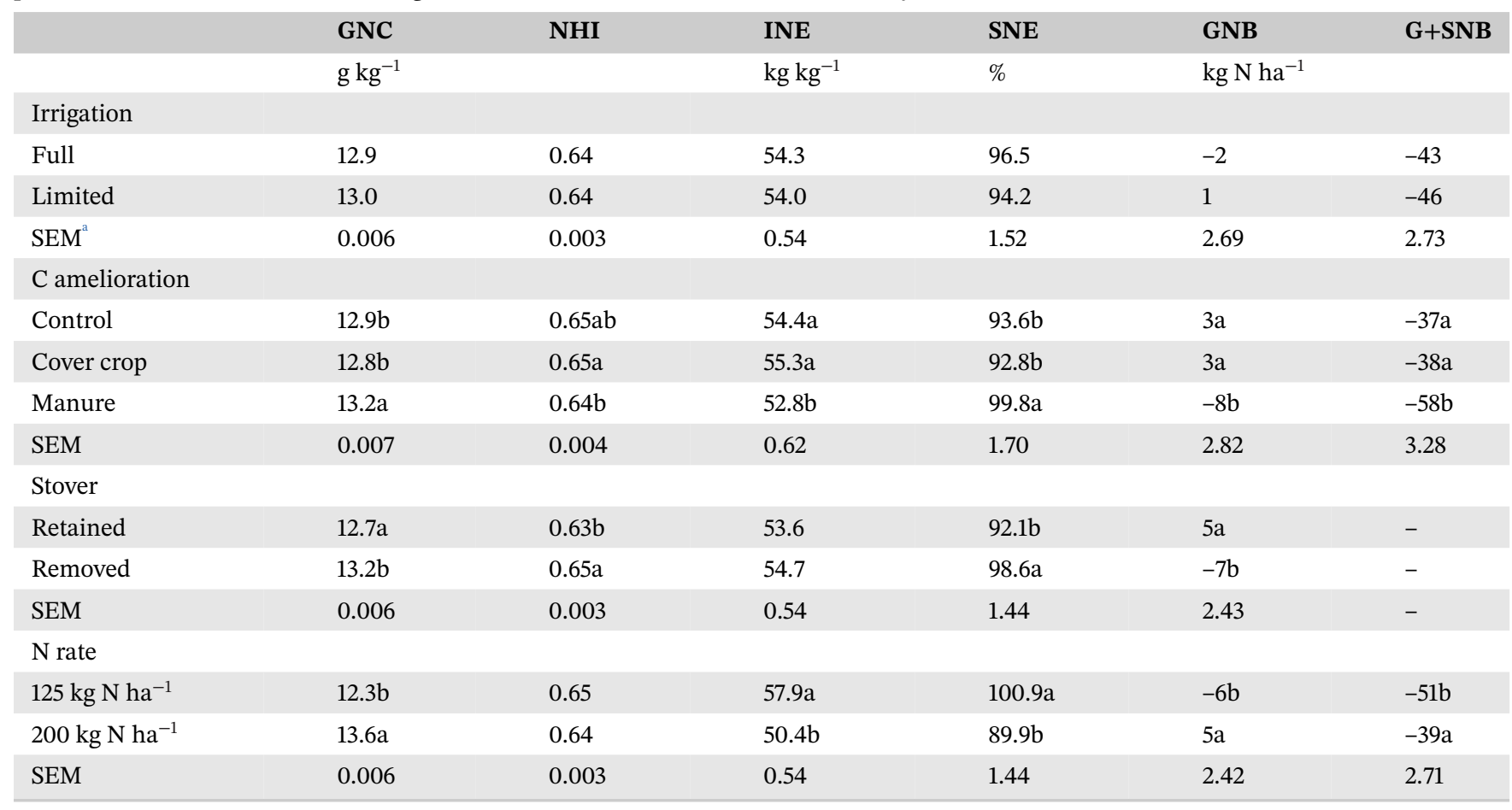

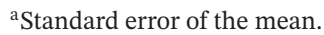

(12.9 $\mathrm{g} \mathrm{kg}^{-1}$ ) (Table 5). The $200 \mathrm{~kg} \mathrm{~N} \mathrm{ha}^{-1}$ fertilizer rate resulted in a higher GNC (13.6 $\left.\mathrm{g} \mathrm{kg}^{-1}\right)$ than the $125 \mathrm{~kg}$ $\mathrm{N} \mathrm{ha}^{-1}$ rate (12.3 $\mathrm{g} \mathrm{kg}^{-1}$; Table 5). Grain $\mathrm{N}$ concentration was higher $(P<.0001)$ with residue removal $\left(13.2 \mathrm{~g} \mathrm{~kg}^{-1}\right)$ than residue retained $\left(12.7 \mathrm{~g} \mathrm{~kg}^{-1}\right)$ (Table 5). An irrigation $\times$ stover interaction was significant $(P=.0436)$ for GNC (Table 4). Limited irrigation with residue removal had the highest GNC $\left(13.3 \mathrm{~g} \mathrm{~kg}^{-1}\right)$ followed by full irrigation with stover removal $\left(13.0 \mathrm{~g} \mathrm{~kg}^{-1}\right)$, whereas GNC under full and limited irrigation were statistically similar with stover retention.

\section{3 | Farmgate $\mathrm{N}$ balance}

Carbon amelioration, nitrogen rate, and stover removal all resulted in farmgate grain $\mathrm{N}$ balance differences (Table 4). Both cover crop and the control resulted in a positive grain $\mathrm{N}$ balance while surface-applied manure resulted in a negative grain $\mathrm{N}$ balance. The $125 \mathrm{~kg} \mathrm{~N} \mathrm{ha}^{-1}$ rate resulted in a negative grain $\mathrm{N}$ balance whereas the $200 \mathrm{~kg}$ $\mathrm{N} \mathrm{ha}^{-1}$ resulted in a slightly positive grain $\mathrm{N}$ balance (Table 5). Farmgate grain $\mathrm{N}$ balance was negative for stover removal while stover retention resulted in a positive grain $\mathrm{N}$ balance (Table 5). Stover harvest resulted in an additional $\mathrm{N}$ removal of $44 \mathrm{~kg} \mathrm{~N} \mathrm{ha}^{-1}$ averaged across $\mathrm{C}$ amelioration and $\mathrm{N}$ rate. When stover harvest $\mathrm{N}$ removal
(Grain $\mathrm{N}+$ Stover $\mathrm{N}$ ) was taken into account, farmgate $\mathrm{N}$ balance results were affected by $\mathrm{N}$ rate $(P=.0026)$ and $\mathrm{C}$ amelioration practice $(P<.0001$; Table 4$)$. Similar to grain $\mathrm{N}$ balance, surface-applied manure resulted in the most negative farmgate stover and grain $\mathrm{N}$ balance $(-58 \mathrm{~kg} \mathrm{~N}$ $\mathrm{ha}^{-1}$ ) while cover crop $\left(-38 \mathrm{~kg} \mathrm{~N} \mathrm{ha}^{-1}\right)$ and the control $\left(-37 \mathrm{~kg} \mathrm{~N} \mathrm{ha}^{-1}\right)$ were statistically similar. The $125 \mathrm{~kg} \mathrm{~N}$ $\mathrm{ha}^{-1}$ rate resulted in a farmgate stover and grain $\mathrm{N}$ balance of $-51 \mathrm{~kg} \mathrm{~N} \mathrm{ha}^{-1}$ and the $200 \mathrm{~kg} \mathrm{~N} \mathrm{ha}^{-1}$ rate resulted in a farmgate $\mathrm{N}$ balance of $-39 \mathrm{~kg} \mathrm{~N} \mathrm{ha}^{-1}$ (Table 5).

\section{5 | DISCUSSION}

Irrigation rate had minimal effect on yield or NUE while stover removal increased grain yield and NUE (Figure 1 and 2; Table 5). Stover removal studies in irrigated, continuous corn systems tend to show no or a positive effect of stover removal on grain yield. (Blanco-Canqui et al., 2017; Halvorson \& Stewart, 2015; Kenney et al., 2015; Ruis et al., 2017; Schmer et al., 2014; Stalker et al., 2015; Wortmann, et al., 2016). Study duration appears to play a role in yield trends from repetitive stover harvests. Grain yield results reported here are similar to other long-term irrigated studies, which showed a corn yield increase from stover removal (Halvorson \& Stewart, 2015; Schmer et al., 2014). In an irrigated, continuous corn study in Colorado, 
corn grain was highest under partial stover removal while stover retention resulted in higher nongrain biomass yield (Halvorson \& Stewart, 2015). Stover removal resulted in biomass and grain yield increases relative to no stover removal for no-till, continuous corn under irrigation in eastern Nebraska (Schmer et al., 2014). Stover removal was lower in grain moisture at combine harvest than stover retention, which may affect field-harvest optimization and grain drying energy requirements.

A cross-site SOC comparison which including this study indicated that stover removal without $\mathrm{C}$ amelioration practices decreased SOC stocks by $6 \%(0-30 \mathrm{~cm})$ compared to stover retention (Stewart et al., 2019). The mechanism for SOC stock loss varied by location but no-till alone was not sufficient to maintain SOC stocks and soil aggregation (Stewart et al., 2019). These results reinforce the concept that soil indicators are the primary mechanism for determining viable stover harvest rates (if any) for a given location and management practice (Obrycki, Karlen, Cambardella, Kovar, \& Birrell, 2018). Further, $\mathrm{C}$ amelioration practices in addition to no-till will likely be required to maintain SOC for this region when corn stover is harvested.

Surface-applied manure or winter cover crops, when used as $\mathrm{C}$ amelioration practices, resulted in higher or similar grain yield as the control (no amelioration practice; Figure 1). Manure application may also reduce $\mathrm{N}$ fertilizer input costs as manure prices trend lower than inorganic $\mathrm{N}$ fertilizer (Park, Vitale, Turner, Hattey, \& Stoecker, 2010). Although using a cover crop did not decrease or increase total biomass or grain yield in this study, cover crops such as winter cereal rye provide additional $\mathrm{C}$ inputs to partially offset $\mathrm{C}$ loss from stover removal. Both cover crops and manure application mitigated stover harvest effects on wet aggregate stability and SOC concentrations for this site in the short-term (Blanco-Canqui et al., 2014). After 6-yr, however, stover harvest impacted surface soil hydraulic properties, and surface SOC (0-5 cm depth) dropped under cover crop with stover removal compared to no stover removal (Sindelar et al., 2019). Winter cereal rye was terminated prior to planting resulting in minimal aboveground biomass $\left(0.8 \mathrm{Mg} \mathrm{ha}^{-1} \mathrm{yr}^{-1}\right)$ in this study (Sindelar et al., 2019). The use of late-termination of winter cereal rye has resulted in similar corn grain yields as early termination while resulting in deceased water erosion potential (Ruis et al., 2017).

Harvest index increased with increasing $\mathrm{N}$ rate in this study, but harvest index was not affected by stover removal in other studies (Sawyer et al., 2017; Sindelar, Lamb, \& Coulter, 2014). In contrast, increased grain yield from stover removal resulted in a higher $\mathrm{HI}$ in the current study. We speculate that increased growingseason soil temperatures from stover removal resulted in a longer grain filling period. Previous research in Minnesota and eastern Nebraska showed no effect of stover removal on NHI (Sindelar et al., 2014; Wortmann et al., 2016). Stover removal affected NHI in a 3-yr study located in central Iowa, though overall differences were relatively small (Sawyer et al., 2017). We found similar results with an increase in NHI with stover removal (Table 5).

Stover removal has been shown to have mixed effects on NUE. Sawyer et al. (2017) noted that stover removal improved NUE metrics that evaluated productivity per unit input but not efficiency gain (e.g., agronomic efficiency or nitrogen recovery efficiency). Stover removal from this study resulted in more consistent effects on NUE (Table 4). Partial factor productivity of $\mathrm{N}$ under stover retention from this study (Figure $2 \mathrm{~g}$ ) is similar to state-wide Nebraska corn systems (Ferguson et al., 2015), while stover removal further increased PFP of N. Higher N uptake by corn stover removal is likely caused by reduced immobilization of applied $\mathrm{N}$ (Wortmann et al., 2016) and increased net soil mineralization (Andraski \& Bundy, 2008) from increased soil temperatures in early summer (Halvorson \& Stewart, 2015; Ruis \& Blanco-Canqui, 2017). Declines in total soil $\mathrm{N}$ stock can occur with repeated stover removal over time (Schmer et al., 2014; Sindelar, et al, 2014) or when compared with stover retention (Halvorson \& Stewart, 2015). The farmgate $\mathrm{N}$ balance from stover removal was negative, yet grain yield was not affected after eight growing seasons. Negative or low farmgate $\mathrm{N}$ balances are common for irrigated corn systems in this region with an average of $7 \mathrm{~kg} \mathrm{~N} \mathrm{ha}^{-1}$ (Grassini \& Cassman, 2012). We speculate that lower farmgate $\mathrm{N}$ balances and overall biomass removal likely contribute to lower soil $\mathrm{N}_{2} \mathrm{O}$ emission fluxes from corn systems with stover removal (Jin et al., 2014). Lower farmgate $\mathrm{N}$ balances within irrigated corn systems tend to result in lower soil $\mathrm{N}_{2} \mathrm{O}$ emissions (Grassini \& Cassman, 2012).

Stover harvest rates in this study $\left(5.7 \mathrm{Mg} \mathrm{ha}^{-1} \mathrm{yr}^{-1}\right.$ ) exceeds both recommended stover harvest amounts and harvest frequency to maintain long-term SOC stocks (Johnson, Novak, \& Varvel, 2014; Karlen et al., 2019). It should be noted that the remaining stover from the stover harvest treatment factor is largely lost from this site due to the stover cutting height $(5 \mathrm{~cm})$, mechanical shredding (residue size reduction), and wind potential for this region (Graham, Nelson, Sheehan, Perlack, \& Wright, 2007). Decreased stover size reduction through the harvesting process likely affects $\mathrm{C}$ and $\mathrm{N}$ soil processes (Stetson, Lehman, \& Osborne, 2018). Average stover harvest for the Corn Belt is approximately $3.6 \mathrm{Mg} \mathrm{ha}^{-1}$, and although total corn acreage harvested for stover is small, the amount of area harvested for stover in the western Corn Belt appears to have increased over the last decade (Mourtzinis 
et al., 2018; Schmer et al., 2017). Currently, conservation practices among corn producers who harvest stover and those who do not harvest stover are similar, suggesting producer adoption of conservation and erosion control measures will be critical (Obrycki \& Karlen, 2018). To date, most stover removal experiments have been designed to remove stover whenever corn is present within the rotation. Management systems that remove stover less frequently have been proposed to increase grain yield and mitigate SOC loss (Halvorson \& Stewart, 2015). New studies or alteration of existing studies may be required to determine how current recommended stover harvest practices (e.g., nonannual harvest frequency) influence long-term grain yield and $\mathrm{N}$ uptake while determining if SOC and other soil properties can be maintained.

\section{6 | SUMMARY AND CONCLUSION}

Total biomass, grain yield, grain moisture, and NUE indicators were evaluated (2011-2018) on a variable irrigated continuous corn study with stover removal and C amelioration practices in south-central Nebraska. Overall, irrigation rates (limited vs full) did not affect grain yield. Incorporating cereal rye as a winter cover crop resulted in similar grain yields as the control (no $\mathrm{C}$ amelioration practice) while surface-applied manure increased grain yield with stover removal. Stover harvest resulted in increased grain yield of $1.02 \mathrm{Mg} \mathrm{ha}^{-1}$. Nitrogen use efficiency indicators were affected by both $\mathrm{N}$ rate and stover harvest with increased NUE for stover harvest and lower $\mathrm{N}$ rate. Overall, greater $\mathrm{N}$ uptake was found with stover removal. This greater $\mathrm{N}$ uptake through greater grain $\mathrm{N}$ concentration and increased grain yield with residue removal resulted in negative farmgate $\mathrm{N}$ balances. The negative farmgate $\mathrm{N}$ balance did not result in grain yield declines averaged over eight growing seasons. There are potential production and economic benefits of incorporating $\mathrm{C}$ amelioration practices, particularly manure, when corn stover is harvested.

\section{ACKNOWLEDGMENTS}

We thank S. Swanson, B. Fann, P. Koerner, D. Walla, R. Harrison, S. Wagner, S. Siragusa-Ortman, G. Slater, P. Ridgway, and the many students who help collect, analyze, and managed this experimental study.

\section{O R C I D}

MartyR. Schmer (10) https://orcid.org/0000-0002-3721-6177

\section{RE F E RE N C ES}

Andraski, T. W., \& Bundy, L. G. (2008). Corn residue and nitrogen source effects on nitrogen availability in no-till corn. Agronomy Journal, 100, 1274-1279. https://doi.org/10.2134/agronj2008.0039
Blanco-Canqui, H., Ferguson, R. B., Jin, V. L., Schmer, M. R., Wienhold, B. J., \& Tatarko, J. (2014). Can cover crop and manure application maintain or improve soil properties after corn stover removal? Soil Science Society of America Journal, 78, 1368-1377. https://doi.org/10.2136/sssaj2013.12.0550

Blanco-Canqui, H., Sindelar, M., Wortmann, C. S., \& Kreikemeier, G. (2017). Aerial interseeded cover crop and corn residue harvest: Soil and crop impacts. Agronomy Journal, 109, 1344-1351. https:// doi.org/10.2134/agronj2017.02.0098

Farmaha, B. S., Eskridge, K. M., Cassman, K. G., Specht, J. E., Yang, H., \& Grassini, P. (2016). Rotation impact on on-farm yield and input-use efficiency in high-yield irrigated maize-soybean systems. Agronomy Journal, 108, 2313-2321. https://doi.org/10.2134/ agronj2016.01.0046

Ferguson, R. B. (2015). Groundwater quality and nitrogen use efficiency in Nebraska's central Platte river valley. Journal of Environmental Quality, 44, 449-459. https://doi.org/10.2134/jeq2014. 02.0085

Fronning, B. E., Thelen, K. D., \& Min, D. H. (2008). Use of manure, compost, and cover crops to supplant crop residue carbon in corn stover removed cropping systems. Agronomy Journal, 100, 17031710. https://doi.org/10.2134/agronj2008.0052

Gentry, L. F., Ruffo, M. L., \& Below, F. E. (2013). Identifying factors controlling the continuous corn yield penalty. Agronomy Journal, 105, 295-303. https://doi.org/10.2134/agronj2012.0246

Graham, R. L., Nelson, R., Sheehan, J., Perlack, R. D., \& Wright, L. L. (2007). Current and potential U.S. corn stover supplies. Agronomy Journal, 99, 1-11. https://doi.org/10.2134/agronj2005.0222

Grassini, P., \& Cassman, K. G. (2012). High-yield maize with large net energy yield and small global warming intensity. Proceedings of the National Academy of Sciences of the United States of America, 109, 1074-1079. https://doi.org/10.1073/pnas.1116364109

Grassini, P., Thorburn, J., Burr, C., \& Cassman, K. G. (2011). Highyield irrigated maize in the Western U.S. Corn Belt: I. On-farm yield, yield potential, and impact of agronomic practices. Field Crops Research, 120, 142-150. https://doi.org/10.1016/j.fcr.2010.09. 012

Halvorson, A. D., \& Stewart, C.E. (2015). Stover removal affects no-till irrigated corn yields, soil carbon, and nitrogen. Agronomy Journal, 107, 1504-1512. https://doi.org/10.2134/agronj15.0074

Irmak, S. (2015). Inter-annual variation in long-term center pivot irrigated maize evapotranspiration (ET) and various water productivity response indices: Part II. Irrigation water use efficiency (IWUE), crop WUE, evapotranspiration WUE, irrigationevapotranspiration use efficiency, and precipitation use efficiency. Journal of Irrigation and Drainage Engineering, 141(5).

Jin, V. L., Baker, J. M., Johnson, J. M. F., Karlen, D. L., Lehman, R. M., Osborne, S. L., ... Wienhold, B. J. (2014). Soil greenhouse gas emissions in response to corn stover removal and tillage management across the US Corn Belt. Bioenergy Research, 7, 517-527. https://doi.org/10.1007/s12155-014-9421-0

Jin, V. L., Schmer, M. R., Wienhold, B. J., Stewart, C. E., Varvel, G. E., Sindelar, A. J., ... Vogel, K. P. (2015). Twelve years of stover removal increases soil erosion without impacting yield. Soil Science Society of America Journal, 79, 1169-1178. https://doi.org/10. 2136/sssaj2015.02.0053

Jin, V. L., Schmer, M. R., Stewart, C. E., Sindelar, A. J., Varvel, G. E., \& Wienhold, B. J. (2017). Long-term no-till and stover retention each decrease the global warming potential of irrigated 
continuous corn. Global Change Biology, 23, 2848-2862. https:// doi.org/10.1111/gcb.13637

Johnson, J. M. F., Novak, J. M., \& Varvel, G. E. (2014). Crop residue mass needed to maintain soil organic carbon levels: Can it be determined? BioEnergy Research, 7, 481-490. https://doi.org/10. 1007/s12155-013-9402-8

Karlen, D. L., Schmer, M. R., Kaffka, S., Clay, D. E., Wang, M. Q., Horwath, W. R., ... Chute, A. G. (2019). Unraveling crop residue harvest effects on soil organic carbon. Agronomy Journal, 111, 9398. https://doi.org/10.2134/agronj2018.03.0207

Kaye, J., Finney, D., White, C., Bradley, B., Schipanski, M., AlonsoAyuso, M., ... Mejia, C. (2019). Managing nitrogen through cover crop species selection in the U.S. mid-Atlantic. PLOS ONE, 14(4), e0215448. https://doi.org/10.1371/journal.pone.0215448

Kenney, I., Blanco, H., Canqui, D., Presley, R, Rice, C. W., Janssen, K., \& Olson, B. (2015). Soil and crop response to stover removal from rainfed and irrigated corn. GCB Bioenergy, 7, 219-230. https://doi.org/10.1111/gcbb.12128

Koelsch, R., \& Shapiro, C. (2006). Determining crop available nutrients from manure. University of Nebraska-Lincoln Extension. http://extensionpublications.unl.edu/assets/html/g1335/build/ g1335.htm

Locker, C. R., Torkamani, S., Larenzi, I. J., Jin, V. L., Schmer, M. R., \& Karlen, D. L. (2019). Field-to-farm gate greenhouse gas emissions from corn stover production in the Midwestern U.S. Journal of cleaner production, 226, 1116-1127. https://doi.org/10.1016/j. jclepro.2019.03.154.

Marcillo, G. S., \& Miguez, F. E. (2017). Corn yield response to winter cover crops: An updated meta-analysis. Journal of Soil and Water Conservation, 72, 226-239. https://doi.org/10.2489/jswc.72.3.226

McLellan, E., Cassman, K. G., Eagle, A. J., Woodbury, P. B., Sela, S., Tonitto, C., ... van Es, H. M. (2018). The nitrogen balancing act: Tracking the environmental performance of food production. Bioscience, 68, 194-203. https://doi.org/10.1093/biosci/bix164

Mitchell, R. B., Schmer, M. R., Anderson, B., Jin, V. L., Balkcom, K., Kiniry, J. R., ... White, P. (2016). Dedicated energy crops and crop residues for bioenergy feedstocks in the Central and Eastern USA. Bioenergy Research, 9, 384-398. https://doi.org/10.1007/s12155-0169734-2

Mourtzinis, S., Rattalino Edreira, J. I., Grassini, P., Roth, A. C., Casteel, S. N., Ciampitti, I. A., ... Conley, S. P. (2018). Sifting and winnowing: Analysis of farmer field data for soybean in the US North-Central region. Field Crops Research, 221, 130-141. https://doi.org/10.1016/j.fcr.2018.02.024

Obrycki, J. F., \& Karlen, D. L. (2018). Is corn stover harvest predictable using farm operation, technology, and management variables? Agronomy Journal, 110, 749-757. https://doi.org/10.2134/ agronj2017.08.0504

Obrycki, J. F., Karlen, D. L., Cambardella, C. A., Kovar, J. L., \& Birrell, S. J. (2018). Corn stover harvest, tillage, and cover crop effects on soil health indicators. Soil Science Society of America Journal, 82, 910-918. https://doi.org/10.2136/sssaj2017.12.0415

Pantoja, J. L., Woli, K. P., Sawyer, J. E., Barker, D. W., \& Al-Kaisi, M. (2015). Stover harvest and tillage system effects on corn response to fertilizer nitrogen. Soil Science Society of America Journal, 79, 1249-1260. https://doi.org/10.2136/sssaj2015.01.0039

Park, S. C., Vitale, J., Turner, J. C., Hattey, J. A., \& Stoecker, A. (2010). Economic Profitability of Sustained Application of Swine Lagoon Effluent and Beef Feedlot Manure Relative to Anhydrous Ammo- nia in the Oklahoma Panhandle. Agronomy Journal, 102, 420-430. https://doi.org/10.2134/agronj2009.0166

Quemada, M., Baranski, M., Nobel-de Lange, M. N. J., Vallejo, A., \& Cooper, J. M. (2013). Meta-analysis of strategies to control nitrate leaching in irrigated agricultural systems and their effects on crop yield. Agriculture Ecosystems and Environment, 174, 1-10. https:// doi.org/10.1016/j.agee.2013.04.018

Redfearn, D. D., Parsons, J., Drewnoski, M., Schmer, M. R., Mitchell, R. B., MacDonald, J., ... Smart, A. (2019). Assessing the value of grazed corn residue for crop and cattle producers. Agricultural \& Environmental Letters, 4, 1-5. https://doi.org/10.2134/ael2018.12. 0066

Ruis, S. J., Blanco-Canqui, H., Jasa, P. J., Ferguson, R. B., \& Slater, G. (2017). Can cover crop use allow increased levels of corn residue removal for biofuel in irrigated and rainfed systems? Bioenergy Research, 10, 992-1004. https://doi.org/10.1007/s12155-017-9858-z

Rudnick, D. R. (2015). Maize evapotranspiration, canopy and stomatal resistances, crop water productivity, and economic analysis for various nitrogen fertilizer rates under full irrigation, limited irrigation, and rainfed settings (PhD diss.). University of Nebraska-Lincoln, Lincoln, NE.

Rudnick, D., Irmak, S., Ferguson, R., Shaver, T., Djaman, K., Slater, G., ... Van Donk, S. (2016). Economic return vs crop water productivity of maize for various nitrogen rates under full irrigation, limited irrigation, and rainfed settings in South Central Nebraska. Journal of Irrigation and Drainage Engineering, 142, 04016017. https://doi.org/10.1061/(ASCE)IR.1943-4774.0001023.

Ruis, S. J., \& Blanco-Canqui, H. (2017). Cover crops could offset crop residue removal effects on soil carbon and other properties: A review. Agronomy Journal, 109, 1785-1805. https://doi.org/10.2134/ agronj2016.12.0735

SAS Institute. (2014). The SAS system for Windows. Release 9.3. Cary, NC: SAS.

Sawyer, J. E., Woli, K. P., Barker, D. W., \& Pantoja, J. L. (2017). Stover removal impact on corn plant biomass, nitrogen, and use efficiency. Agronomy Journal, 109, 802-210. https://doi.org/10.2134/ agronj2016.11.0672

Schmer, M. R., Brown, R. M., Jin, V. L., Mitchell, R. B., \& Redfearn, D. D. (2017). Corn residue use by livestock in the United States. Agricultural \& Environmental Letters, 10, 992-1004. https://doi.org/10. 2134/ael2016.10.0043

Schmer, M. R., Varvel, G. E., Follett, R. F., Jin, V. L., \& Wienhold, B. J. (2014). Tillage and residue management effects on soil carbon and nitrogen under irrigated continuous corn. Soil Science Society of America Journal, 78, 1987-1996. https://doi.org/10.2136/sssaj2014. 04.0166

Seifert, C. A., Roberts, M. J., \& Lobell, D. B. (2017). Continuous corn and soybean yield penalties across hundreds of thousands of fields. Agronomy Journal, 109, 541-548. https://doi.org/10.2134/ agronj2016.03.0134

Sims, A. L., Schepers, J. S., Olson, R. A., \& Power, J. F. (1998). Irrigated corn yield and nitrogen accumulation response in a comparison of no-till and conventional till: Tillage and surface-residue variables. Agronomy Journal, 90, 630-637. https://doi.org/10.2134/ agronj1998.00021962009000050011x

Sindelar, A. J., Coulter, J. A., Lamb, J. A., \& Vetsch, J. A. (2013). Agronomic responses of continuous corn to stover, tillage, and nitrogen management. Agronomy Journal, 105, 1498-1506. https://doi.org/10.2134/agronj2013.0181 
Sindelar, A. J., Lamb, J. A., \& Coulter, J. A. (2014). Short-term stover, tillage, and nitrogen management affect near-surface soil organic matter. Soil Science Society of America Journal, 79, 251-260. https://doi.org/10.2136/sssaj2014.08.0337

Sindelar, M., Blanco-Canqui, H., Jin, V. L., \& Ferguson, R. (2019). Cover crops and corn residue removal: Impacts on soil hydraulic properties and their relationship with carbon. Soil Science Society of America Journal, 83, 221-231. https://doi.org/10.2136/sssaj2018. 06.0225

Stalker, A., Blanco-Canqui, H., Gigax, J., McGee, A., Shaver, T., \& van Donk, S. (2015). Corn residue stocking rate affects cattle performance but not subsequent grain yield. Journal of Animal Science, 93, 917-924. https://doi.org/10.2527/jas.2015-9259

Stetson, S. J., Lehman, R. M., \& Osborne, S. L. (2018). Corn residue particle size affects soil surface properties. Agricultural \& Environmental Letters, 3, 180004.

Stewart, C. E., Roosendaal, D. L., Sindelar, A. J., Pruessner, E., Jin, V. L., \& Schmer, M. R. (2019). Soil property changes from stover removal under irrigation: A multi-location assessment. Soil Science Society of America Journal, 83, 733-742. https://doi.org/10. 2136/sssaj2018.09.0352.

Thelen, K. D., Fronning, B. E., Kravchenko, A., Min, D. H., \& Robertson, G. P. (2010). Integrating livestock manure with a corn-soybean bioenergy cropping system improves short-term carbon sequestration rates and net global warming potential. Biomass Bioenergy, 34, 960-966. https://doi.org/10.1016/j.biombioe.2010.02.004

Varvel, G. E., \& Peterson, T. A. (1990). Nitrogen fertilizer recovery by corn in monoculture and rotation systems. Agronomy Journal, 82, 935-938. https://doi.org/10.2134/agronj1990. 00021962008200050019x
Verma, S. B., Dobermann, A., Cassman, K. G., Walters, D. T., Knops, J. M., Arkebauer, T. J., ... Yang, H. (2005). Annual carbon dioxide exchange in irrigated and rainfed maize-based agroecosystems. Agricultural and Forest Meteorology, 131, 77-96. https://doi.org/10. 1016/j.agrformet.2005.05.003

Wilhelm, W. W., Hess, J. R., Karlen, D. L., Johnson, J. M. F., Muth, D. J., Baker, J. M., ... Varvel, G. E. (2010). Review: Balancing limiting factors and economic drivers for sustainable Midwestern US agricultural residue feedstock supplies. Industrial Biotechnology, 6, 271-287. https://doi.org/10.1089/ind.2010.6.271

Woli, K. P., Boyer, M. J., Elmore, R. W., Sawyer, J. E., Abendroth, L. J., \& Barker, D. W. (2016). Corn era hybrid response to nitrogen fertilization. Agronomy Journal, 108, 473-486. https://doi.org/10. 2134/agronj2015.0314

Wortmann, C. S., \& Shapiro, C. A. (2008). Calculating the value of manure for crop production (University of Nebraska-Lincoln NebGuide G1519). University of Nebraska-Lincoln, Lincoln, NE.

Wortmann, C. S., Shapiro, C. A., \& Schmer, M. R. (2016). Residue harvest effects on irrigated, no-till corn yield and nitrogen response. Agronomy Journal, 108, 384-390 https://doi.org/10.2134/ agronj2015.0361

How to cite this article: Schmer MR, Jin VL, Ferguson RB, Wienhold BJ. Irrigation, carbon amelioration, nitrogen, and stover removal impacts on continuous corn. Agronomy Journal. 2020;112:2506-2518. https://doi.org/10.1002/agj2.20192 